\title{
Generosity's antecedents and outcomes - A proposed relationship between Generosity and Intention in Indonesia's BPJS Kesehatan
}

\author{
Diena Dwidienawati \\ Sri Bramantoro Abdinagoro \\ Bina Nusantara University, Indonesia
}

\begin{abstract}
Key Words
BPJS Kesehatan, Generosity, Positive Emotion, Intention
\end{abstract}

\begin{abstract}
In one preliminary descriptive study, the authors look for the satisfaction of and intention towards BPJS Kesehatan in Indonesia, revealing that despite the high un-satisfaction rate, ninety-one per cent of members are still expressing their intention continue paying insurance premium. The most mentioned reason for continued membership is helping others. Therefore, the preliminary study concludes that there might be a role of generosity influencing intention. This study aims to develop a conceptual model linking generosity to intention. The method used for critical review is PRISMA systematic review. The result of the critical review is used as the based for concept development. More than three hundred publications published after 2007 in Science Direct were screened with key words "generosity" and "charity". Finally, thirty journals were included in this review. The finding is that the most discussed topics are terminology (3 journals), motivation (16 journals), consequences (5 journals), and attributes of generosity (5 journals). Based on the review results, two possible relationships between generosity and intention are proposed. The first is that generosity, mediated by positive emotion, will influence intention. The second is that generosity has a direct influence on intention. It concludes with the need for further study to find empirical validation of the two possible relationships between generosity and intention. This is the first study proposed to link the generosity to intention.
\end{abstract}

Corresponding author: Diena Dwidienawati

Email addresses for corresponding author: diena.tjiptadi@gmail.com

First submission received: 7th May 2017

Revised submission received: 28 th June 2017

Accepted: 18th August 2017

\section{Introduction}

Indonesia is one of several low and middle-income countries aiming to improve their health financing system and to implement universal health coverage (UHC). The Government of Indonesia issued Law No. 40 of 2004 regarding the implementation of the National Social Security System(President Republik Indonesia, 2004). This law was issued based on the principles of humanity, benefit, and social justice for all Indonesian citizens. Furthermore, the government established Social Security Agency or Badan Penyelenggara Jaminan Sosial (BPJS) as an agency body to ensure the implementation of the system. One of the programs is BPJS Kesehatan, which covers health insurance for all Indonesia.

Starting just within the last three years, January 2014, BPJS Kesehatan has successfully had large coverage. As of January 2017, BPJS Kesehatan has 172.97 million members, according to its official website. It is considered the biggest single payer institution of the Universal Health Coverage program in the world(Teh, 2015). Government of Indonesia targets to reach 100\% coverage by 2019.

The rapid expansion of insurance coverage has created a demand which cannot be met by the current healthcare system(Bredenkamp et al., 2015). The sudden increase of demand will disrupt the delivery of service, especially in public hospitals. The disruption of service, as a consequence, will influence the satisfaction level. The Centre for Health Economic and Policies Study from the University of Indonesia showed that the satisfaction level of hospital service is $54 \%$. The satisfaction level of doctor service is $44 \%$ (Thabrany, 2016). 
One descriptive study, with 123 samples done by the authors, confirms that the satisfaction level of the service of BPJS Kesehatan is still low. Sixty-one per cent of respondents rate the BPJS Kesehatan service as positive (satisfied to very satisfied). Thirty-nine per cent of respondents still consider the service unsatisfying. Despite the high un-satisfaction rate, both users and non-users are still expressing their intention to continue BPJS Kesehatan membership. Intention rate is 91 per cent. The most mentioned reason for continuing membership is helping others (27 respondents). Therefore, there might be a role of generosity influencing intention(Dwidienawati and Abdinagoro, 2017).

Generosity is defined as giving to others - especially giving to others at a level that exceeds minimum needs or obligation (Wilcox and Dew, 2016). Generosity is a way of expressing love. It tends to the well-being of those to whom something is given. Generosity is shown in various way of giving. It can be giving money, possession, time, attention, aid, encouragement, emotional availability, and more.

However, "The more I give to thee the more I have" Juliet says to Romeo. Generosity is known not only to be beneficial for the recipient, but also beneficial to the donor. The act of giving is good for those who practice it (Smith and Davidson, 2014). Generosity is not identical to pure altruism, since people can be generous for reasons that serve their own interest as well as those of others. Therefore, we can say that generosity is a virtue that serves side, donors and recipients. It is for the good of others, the recipients, and also benefits the donors(Smith and Davidson, 2014).

Generosity does not usually work in simple, zero sum, win/lose ways. It works unexpectedly; counter intuitively, win-win. Generosity is not producing net losses. In general, the more generously people give, the more of many goods they receive in turn. Sometimes they receive the same kind of thing that they gave, such as money, time or attention. More often and importantly, generous people gain back goods that are even more valuable than what they gave, namely happiness, health, a sense of purpose in life, and personal growth (Smith and Davidson, 2014).

Charitable giving involves a huge amount of money. In the U.S., the total money given to charity in 2011 alone was $\$ 298.42$ billion - over 2\% of U.S. GDP and it is estimated to grow(Chuan and Samek, 2014). People currently are more generous. The act of giving has been promoted in many countries. According to World Giving Index published by the Charities Aid Foundation, almost a third of the world population had given money to charity, and $45 \%$ of the world had been 'good Samaritans' and helped strangers(Datablog, 2010).

Business saw the potential economic benefit of this more generous attitude. Cause Related Marketing was introduced as approach to combine act of giving and business purpose. CRM has proven to be an effective marketing and fundraising tool by involving companies in helping behaviors. CRM enables customers to view purchasing as a pro-social behavior. However, in academia, there are only a few literatures on the subject studying how generosity initiative influences customers' loyalty or intention to continue the relationship with the company(Choi and Seo, 2017).

In order to gain more understanding to develop a relation model of generosity to customer intention to continue the relationship with the company, the authors do a critical review of available journals on generosity.

On Science Direct, search results using the keywords "generosity", "charity", and "intention" reveal more than 60,000 publications. More than eleven thousand publications are from the last five years (2012-2016). In 2017 only, within 2 months alone, there are more than 500 publications on the topic of generosity or charity alone. What is so fascinating about generosity? Why have researchers put in such efforts to establish empirical evidence? What topics are covered in the latest study on generosity? This critical review is done to answer those questions. The other objective of this critical review is to establish a base to develop the relationship model of generosity to intention.

\section{Methodology}

The authors used PRISMA systematic review stepwise (Liberati et al., 2009). From Science Direct, with "generosity" or "charity" as keywords, the authors found more than 60,000 journal publications. The authors then limited the source to social science journals, namely Journal of Social Medicine, Journal of Public Economic, Procedia -Social and Behavior, Journal of Economic Behavior and Organization. The authors further limited the topic to social, public, behavioral science, individual behavior, public 
economic, people, and participant, and limited the date of publication to those later than 2007. This search result yields 231 journals.

The authors added search terms from the same sources with the keywords "generosity" and "intention", with the same limitation; an additional 80 journals were discovered. After excluding duplication and checking the relevancy, the final number of journals for reviewing purposes totals thirty.

\section{Result}

The full-text journal review of thirty journals found that there are four main topic categories. The first one is the definition of generosity. The second one discusses the motivation of people being generous and what make them more generous. The third category is about the consequences of generosity. The last category is various attributes influencing generosity.

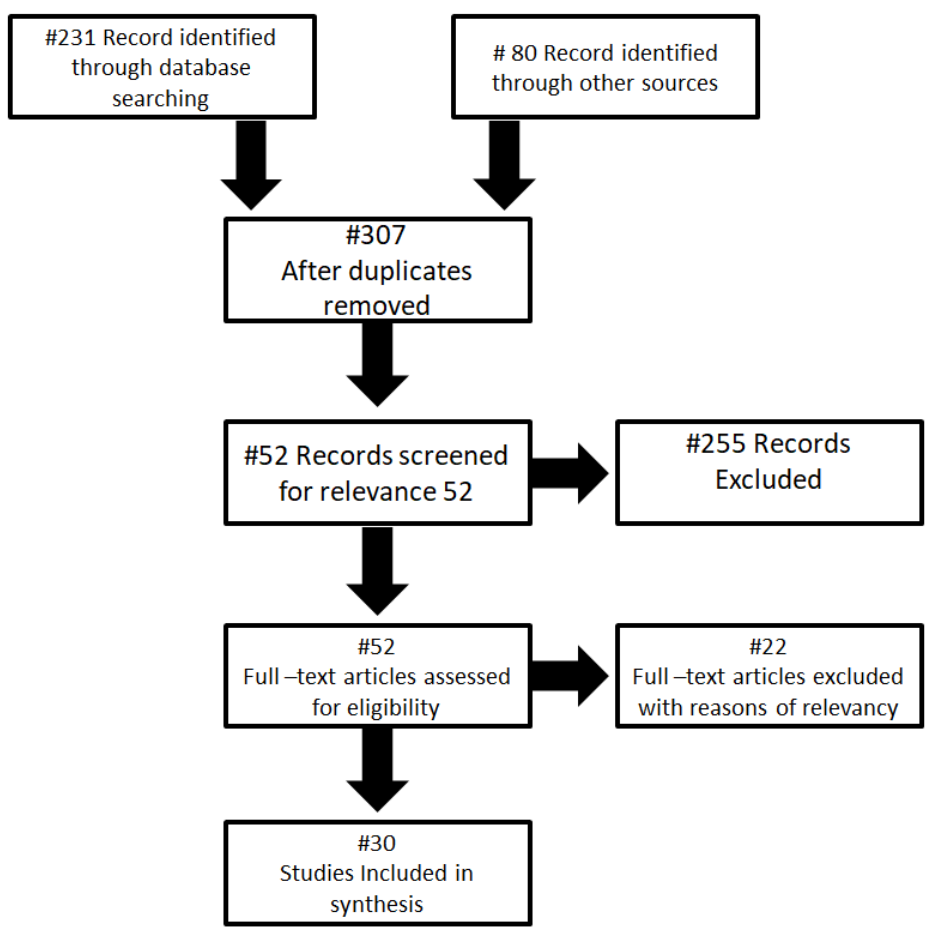

\subsection{Definition of Generosity}

Figure 1. PRISMA Systematic Review

Generosity is defined as giving to others - especially giving to others at a level that exceeds minimum needs or obligation (Wilcox and Dew, 2016). Generosity comes in various ways, such as giving money, possession, time, attention, aid, encouragement, emotional availability, and more.

Three publications were found that define and give terminology related to generosity: Codrea (2014), Strauss, Baer, \& Cavanagh (2016), and Jensen (2016).

Codrea (2014) reveals the definition of gift from an anthropological perspective, which is different from the rigid civil notion of donation. Gift is different from donation since it is not free, not voluntary, and not unilateral. Gift is subject to triple obligation: to give, to receive, and to reciprocate. This may be the reason why people sometimes still expect reciprocity when they give something to others.

Strauss et al. (2016) talk about compassion. According to him despite widely increasing attention, the definition of compassion is still not fully agreed upon and lacks robust measure. He proposes that there are five elements of compassion, which are recognizing suffering, understanding the universality of human suffering, feeling for the person suffering, tolerating uncomfortable feelings, and motivation to act/acting to alleviate suffering. Compassion somehow is part of generosity.

Jensen (2016) discusses prosocial behavior. According to him, prosocial behavior is behavior which is intended to benefit others. Informing, comforting, sharing, and helping are examples of prosocial behaviors. 


\subsection{What motivates people to be generous and what makes people become more generous?}

Various motivations are behind the act of giving, and can be economical reasoning versus social reasoning. Extrinsic incentives are economically relevant. Tangible reward (e.g. money, reciprocal gift) and intangible reward (e.g. reputation, gain long term cooperation, and avoiding social sanction) are types of extrinsic incentives. Social rationale is when the reason behind giving is to gain intrinsic rewards (DeClerck, Boone and Emonds, 2013). Intrinsic rewards are rewards such as feeling satisfied, "Warm Glow", and positive feelings from the experience of donating. The last motivation is pure altruism, which is empathy to help others (Verhaert and Van den Poel, 2011; Dickert et al., 2011; Basil et al., 2008) in (Wang and Tong, 2015).

There are nine journals out of thirty which review the motivation of people for being generous. The hoping to get intrinsic reward is reported by various authors (DeClerck, Boone and Emonds, 2013; Hur, 2013; Greenberg, 2014; Sharp and Randhawa, 2014; Lynn, 2015; Natter and Kaufmann, 2015; Kandul, 2016; Llamas and Uth, 2016; Liu and Hao, 2017). They argue that people doing good to others, such as prosocial acts, tipping, giving money to strangers, and voluntary payment, do so because they can gain the feeling of pleasure, "Warm Glow", and feeling more connected to humankind.

Llamas \& Uth (2016) argue that main reasons people are generous are to gain luxury, feel the pleasure and purpose, and feel connected with humankind (intrinsic). Declerck et al. (2013) state that people enjoy giving because of the reward of human cooperation, not because of natural compensation. Greenberg (2014) in his study in prosocial behavior demonstrates that the motivation of prosocial behavior is both intrinsic and extrinsic. The prominent motives behind giving money to others are first they don't like inequality, second, they like to have "Warm Glow", and last the solidarity of needy (Kandul 2016).

Only three journals are about extrinsic reward motivation. Natter \& Kaufmann (2015) say the reason people initiate a voluntary payment is because they expect to accept reciprocal acts. Greenberg (2014) in his study demonstrates that the motivations of prosocial behaviors are both intrinsic and extrinsic. The motivation of avoiding social sanction is only mentioned by Greenberg and Hur. Giving to others, according to them, is for moral judgement and following social norm.

Sharp \& Randhawa (2014), Hur (2013), and Kandul (2016), however, show that pure concern to others is the main motivation of being generous (pure altruism). According to them, selfishness is not the norm of humankind. Hur (2013) mentions that the motivations of prosocial behaviors are mainly empathic and moral judgement. Sharp \& Randhawa (2014) further strengthen the evidence. They argue that the motivation of altruism is concern for the welfare of others and it is driven by emphatic. Kandul (2016) states that the prominent motives behind giving money to others are first they don't like inequality, second, they like to have warm glow, and last the solidarity of needy.

Human beings can be more generous. Zaleskiewicz, Gasiorowska, \& Kesebir(2015), Kandul(2016), Sollberger, Bernauer, \& Ehlert(2016), Grolleau, Sutan, \& Vranceanu(2016), Cryder \& Loewenstein (2015), Charles-sire, Guéguen, Meineri, Martin, \& Bullock(2014) and Rotemberg(2014) are researching those particular reasons. The thought of mortality, getting detailed information about the charity itself, interacting with a poorer stranger, already receiving help, and interacting with generous people are some of the reasons causing people to become more generous. Sollberger et al. (2016) shows that stress can increase the act of kindness to donate even though it decreases the amount of donation. Rotemberg (2014) shows that seeing others donate can motivate people to also donate. Generosity is contagious

\subsection{Consequences of Generosity}

Previous studies show that being generous leads to more happiness and satisfaction(Aknin et al., 2013)(Matz, Gladstone and Stillwell, 2016)(Anik et al., 2009). Giving money use both cognitive and emotional processes(Corcoran, 2015). Corcoran (2015) argued that positive emotion played important role in people contributing money. Anik, Norton, Aknin, \& Dunn (2013) in their experimental study showed that giving prosocial bonuses in the form of donations to charity lead to happier and more satisfied employees.

From thirty studies reviewed, only three studies see the consequences of generosity: Aknin et al. (2013), Yoruk (2014), and Lin (2015). Aknin et al. (2013) contributes to empirical evidence on the 
consequences of generosity. He suggests that prosocial impact unleashes the emotional rewards of giving. The study further shows that helping is most likely to lead to happiness when helpers know they have assisted another person in a meaningful way.

Yoruk (2014) states that charitable giving has positive spill over, affecting overall health status and decrease the probability of suffering from several health problems. Charitable subsidies are associated with decreasing the probability of lung disease, emotional and psychological problems, and arthritis. Even though the results show charitable acts associated with the decreasing probability of suffering from other health related problems such as high blood pressure, diabetes, cancer, heart attack, and obesity, the impact on these outcomes is not statistically significant.

Lin (2015) concludes that generosity will increase the feeling of gratitude. Gratitude may lead to increased self-esteem and to improved well-being.

The satisfaction level of being generous can be elevated and eliminated. Rudd, Aaker, \& Norton (2014) mentions that framing concrete goals of prosocial acts brings greater happiness. The reminder about one's responsibility to help others will make people feel better about contributing (Whillans, Wispinski and Dunn, 2016). Aknin et al. (2013) also shows that happiness because of giving money can be elevated when the donor knows how the funds are used. Goal gradient can also increase satisfaction of contribution(Cryder and Loewenstein, 2015). People contribute because of mostly intrinsic incentive, which is also discussed by Chuan \& Samek (2014), while Wang \& Tong (2015) show that exposing or declaring donations to others by the recipients will diminish the satisfaction of contribution.

\subsection{Attributes of Generosity}

Woman might show more empathy, kindness, and desire to help others. Men display less empathetic behavior. However, the act of being prosocial is similar. Nielson, Padilla-walker, \& Holmes(2017) argue that there is no difference between man and woman regarding prosocial behavior.

Lynn \& Starbuck (2015) show that the willingness to tip is influenced by attitude and sensitivity of duty. The difference of culture also influences prosocial behavior. A culture with a communal norm expects less reciprocity when compared to an individual culture(Miller et al., 2014). High status individuals give when they expect reciprocity and low status individuals give out of gratitude(Liu and Hao, 2017). Choi \& Seo (2017) show that personality, status-seeking, and non-status-seeking have different motivations in giving.

\begin{tabular}{|c|c|c|}
\hline Topic & Author & Description \\
\hline Terminology (3 journals) & $\begin{array}{l}\text { (Strauss et al. 2016),(Jensen 2016) and } \\
\text { (Codrea 2014) }\end{array}$ & $\begin{array}{l}\text { Different definition of gift and donation from anthrological } \\
\text { perspective. Definition of Prosocial and compassion. }\end{array}$ \\
\hline \multirow[t]{2}{*}{$\begin{array}{l}\text { Motivation of being generous (15 } \\
\text { Journals) }\end{array}$} & $\begin{array}{l}\text { (Llamas \& Uth 2016), (Declerck et al. 2013), } \\
\text { (Natter \& Kaufmann 2015),(Greenberg } \\
\text { 2014), (Sharp \& Randhawa 2014), (Hur } \\
\text { 2013), (Lynn 2015), (Kandul 2016), (Liu \& } \\
\text { Hao 2017) }\end{array}$ & $\begin{array}{l}\text { Motivation of being generous are extrinsic incentives, intrinsic } \\
\text { incentive and pure virtue. }\end{array}$ \\
\hline & $\begin{array}{l}\text { (Zaleskiewicz et al. 2015), (Kandul 2016), } \\
\text { (Sollberger et al. 2016), (Grolleau et al. } \\
\text { 2016), (Cryder et al. 2013), (Charles-sire et } \\
\text { al. 2014)),(Rotemberg 2014) }\end{array}$ & $\begin{array}{l}\text { People become more generous beacuse of thought of mortality, } \\
\text { getting detail information about the charity itself, interact with } \\
\text { poorer stranger, receiving help and interact with generous } \\
\text { people, seeing other donate and stress. }\end{array}$ \\
\hline \multirow[t]{2}{*}{$\begin{array}{l}\text { Consequences of generosity }(5 \\
\text { journals) }\end{array}$} & $\begin{array}{l}\text { (Aknin et al. 2013), (Yoruk 2014) and (Lin } \\
\text { 2015) }\end{array}$ & $\begin{array}{l}\text { Happiness and health outcomes are the consequences of being } \\
\text { generous. }\end{array}$ \\
\hline & $\begin{array}{l}\text { (Rudd et al. 2014), (Whillans et al. 2016), } \\
\text { (Aknin et al. 2013), (Chuan \& Samek 2014), } \\
\text { (Wang \& Tong 2015), (Cryder \& } \\
\text { Loewenstein 2015) }\end{array}$ & $\begin{array}{l}\text { The satisfaction or happiness level increase when framing } \\
\text { concrete, reminded about responsibility to help, know how the } \\
\text { funds are used and goal gradient. Exposing or declaring donation } \\
\text { to others or recipients will diminish the satisfaction of } \\
\text { contribution. }\end{array}$ \\
\hline $\begin{array}{l}\text { Attributes of generosity ( } 5 \\
\text { Journals) }\end{array}$ & $\begin{array}{l}\text { (Nielson et al. 2017),(Lynn \& Starbuck } \\
\text { 2015),(Miller et al. 2014) } \\
\text { (Liu \& Hao 2017),(Choi S \& Seo 2017) }\end{array}$ & $\begin{array}{l}\text { Culture and personality influnce one generosity but no gender } \\
\text { influence. }\end{array}$ \\
\hline
\end{tabular}

Table 1. Topic Highlight from 30 journals 


\section{Discussion}

Generosity comes in various ways, whether giving money, possession, time, attention, aid, encouragement, emotional availability, and more. However, generosity is not identical to pure altruism, since people can be generous for reasons that serve their own interest as well as those of others. Therefore, that generosity is a virtue that serves both sides, as it is for the good of others and also beneficial for the donor (Smith \& Davidson, 2014).

The critical review from thirty journals on "generosity" reveals that being generous is motivated by pure altruistic reasons (empathy to help others) (Hur, 2013; Kandul, 2016; Sharp \& Randhawa, 2014), intrinsic incentives (the feeling of pleasure, "Warm Glow", and being more connected to humankind) (Declerck et al., 2013; Greenberg, 2014; Hur, 2013; Kandul, 2016; Liu \&Hao, 2017; Llamas \&Uth, 2016; Lynn, 2015; Natter \& Kaufmann, 2015; Sharp \& Randhawa, 2014), and extrinsic incentives (hoping for reciprocity, increase reputation, and avoiding social sanction) (Greenberg, 2014; Hur, 2013; Natter \& Kaufmann, 2015).

Being generous may further lead to happiness, well-being, and other positive health outcomes. The relationship of happiness, positive emotion, and satisfaction to intention has been show in various (Barclay, 2013; Su and Hsu, 2013; Corcoran, 2015; Grolleau, Sutan and Vranceanu, 2016; Urueña and Hidalgo, 2016; Whillans, Wispinski and Dunn, 2016). Therefore, the authors propose a relationship between generosity, positive emotion, and intention.

P1: Generosity is mediated by positive emotion and will positively influence intention.

The other motivation of generosity is pure altruism. People are giving, sharing, and contributing because they are moved by inequality, solidarity of needy, helping others, concerned with the welfare of others, and are driven by empathy (Hur, 2013; Kandul, 2016; Sharp \& Randhawa, 2014) From that evidence the authors can draw the other possible direct relationship of generosity to intention.

P2: Generosity has a positive direct influence on intention.

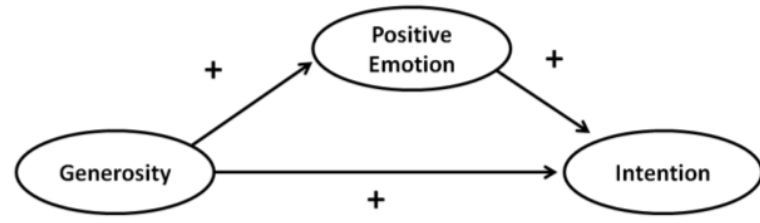

Figure 2. Propose Model Relationship of Generosity to Intention

\section{Conclusion}

In a descriptive study done by the authors to see the satisfaction of and intention towards BPJS Kesehatan in Indonesia, the authors found that despite the high un-satisfaction rate (39 per cent), 91 per cent express their intentions to continue paying insurance premiums. The most mentioned reasons for continuing membership is helping others (27 respondents). Therefore, the conclusion of the study is that there might be a role of generosity in influencing intention (Dwidienawati and Bramantoro, 2017).

Being generous is motivated by pure altruistic reasons (Hur, 2013; Kandul, 2016; Sharp \& Randhawa, 2014), intrinsic incentives (Declerck et al., 2013; Greenberg, 2014; Hur, 2013; Kandul, 2016; Liu \& Hao, 2017; Llamas \&Uth, 2016; Lynn, 2015; Natter \& Kaufmann, 2015; Sharp \& Randhawa, 2014) and extrinsic incentives (Greenberg, 2014; Hur, 2013; Natter \& Kaufmann, 2015). The other motivation is pure altruism.

Drawing from above evidences, the authors suggest that there are two possible relationships between generosity and intention. The first relationship is that generosity is mediated by positive emotion, which will positively influence intention. The second relationship is that generosity has a positive direct influence on intention.

The limitation of this study is that the critical review is only based on one source which is Science Direct. Broaden sources might give more insight such as other possible variables link generosity to intention. Other limitation of this study is that it is still a conceptual model. Further study to discover empirical validation of the two possible relationships between generosity and intention should be done. 
Further evidence will contribute both to theoretical and practical implication. The theoretical contribution will be the first study to provide evidence of the relationship between generosity and intention. The practical implication will be the insight for manager that "generosity" topic can be used to improve customers' intention.

\section{References}

Aknin, L. B., Dunn, E. W., Whillans, A. V, Grant, A. M. and Norton, M. I. (2013) 'Making a difference matters: Impact unlocks the emotional benefits of prosocial spending', Journal of Economic Behavior and Organization. Elsevier B.V., 88, pp. 90-95. doi: 10.1016/j.jebo.2013.01.008.

Anik, L., Aknin, L. B., Norton, M. I. and Dunn, E. W. (2009) 'Feeling Good about Giving: The Benefits (and Costs) of Self-Interested Charitable Behavior', Harvard Business School.

Anik, L., Norton, M. I., Aknin, L. B. and Dunn, E. W. (2013) Prosocial Bonuses Increase Employee Satisfaction and Team Performancec, Harvard Business School.

Barclay, P. (2013) 'Evolution and Human Behavior Strategies for cooperation in biological markets, especially for humans', Evolution and Human Behavior. Elsevier Inc., 34(3), pp. 164-175. doi: 10.1016/j.evolhumbehav.2013.02.002.

Bredenkamp, C., Evans, T., Lagrada, L., Langenbrunner, J., Nachuk, S. and Palu, T. (2015) 'Social Science \& Medicine Emerging challenges in implementing universal health coverage in Asia', Social Science $\mathcal{E}$ Medicine. Elsevier Ltd, 145, pp. 243-248. doi: 10.1016/j.socscimed.2015.07.025.

Charles-sire, V., Guéguen, N., Meineri, S., Martin, A. and Bullock, A. (2014) 'Transfusion and Apheresis Science The effect of priming with a love concept on blood donation promise', Transfusion and Apheresis Science. Elsevier Ltd, 50(1), pp. 87-91. doi: 10.1016/j.transci.2013.10.009.

Choi, J. and Seo, S. (2017) 'Management Goodwill intended for whom? Examining factors influencing conspicuous prosocial behavior on social media', International Journal of Hospitality Management. Elsevier Ltd, 60, pp. 23-32. doi: 10.1016/j.ijhm.2016.09.014.

Chuan, A. and Samek, A. S. (2014) "“Feel the Warmth" glow: A field experiment on manipulating the act of giving', Journal of Economic Behavior and Organization. Elsevier B.V., 108, pp. 198-211. doi: 10.1016/j.jebo.2014.09.011.

Codrea, C. (2014) 'The Legal Frame of the Gift in Ideal Contexts of Authority', Procedia - Social and Behavioral Sciences. Elsevier B.V., 149, pp. 206-211. doi: 10.1016/j.sbspro.2014.08.218.

Corcoran, K. E. (2015) 'Thinkers and feelers: Emotion and giving', Social Science Research. Elsevier Inc., 52, pp. 686-700. doi: 10.1016/j.ssresearch.2014.10.008.

Cryder, C. and Loewenstein, G. (2015) 'Goal gradient in helping behavior', Journal of Experimental Social Psychology. Elsevier Inc., 49(6), pp. 1078-1083. doi: 10.1016/j.jesp.2013.07.003.

Datablog (2010) 'Charitable giving by country: who is the most generous ?', The Guardian, pp. 1-13.

DeClerck, C. H., Boone, C. and Emonds, G. (2013) 'Brain and Cognition When do people cooperate? The neuroeconomics of prosocial decision making', Brain and Cognition. Elsevier Inc., 81(1), pp. 95-117. doi: 10.1016/j.bandc.2012.09.009.

Dwidienawati, D. and Abdinagoro, S. B. (2017) ‘Does Generosity Influence Intention to Continue Paying Insurance Premium? Case of Indonesia's BPJS Kesehatan', in 4th Global Conference on Business and Social Sciences, p. 117.

Greenberg, A. E. (2014) 'On the complementarity of prosocial norms: The case of restaurant tipping during the holidays', Journal of Economic Behavior and Organization. Elsevier B.V., 97, pp. 103-112. doi: 10.1016/j.jebo.2013.10.014.

Grolleau, G., Sutan, A. and Vranceanu, R. (2016) 'Research in Economics Do people contribute more to intra-temporal or inter-temporal public goods ?', Research in Economics. Elsevier, 70(1), pp. 186-195. doi: 10.1016/j.rie.2015.05.001.

Hur, Y. (2013) 'J.P. Rushton' s contributions to the study of altruism', PERSONALITY AND INDIVIDUAL DIFFERENCES, 55, pp. 247-250. doi: 10.1016/j.paid.2012.05.016.

Jensen, K. (2016) 'Prosociality', Current Biology, 26(August), pp. R739-R755. doi: 10.1016/j.cub.2016.07.025.

Kandul, S. (2016) 'Ex-post blindness as excuse? The effect of information disclosure on giving', JOURNAL OF ECONOMIC PSYCHOLOGY. Elsevier B.V., 52, pp. 91-101. doi: 10.1016/j.joep.2015.11.006. 
Liberati, A., Altman, D. G., Tetzlaff, J., Mulrow, C., Gøtzsche, P. C. and John, P. A. (2009) 'The PRISMA statement for reporting systematic reviews and meta-analyses of studies that evaluate healthcare interventions : explanation and elaboration', BMJ, 399, pp. 1-28. doi: 10.1136/bmj.b2700.

Lin, C. (2015) 'Self-esteem mediates the relationship between dispositional gratitude and well-being', PERSONALITY AND INDIVIDUAL DIFFERENCES. Elsevier Ltd, 85(August), pp. 145-148. doi: 10.1016/j.paid.2015.04.045.

Liu, C. and Hao, F. (2017) 'Reciprocity belief and gratitude as moderators of the association between social status and charitable giving', Personality and Individual Differences. Elsevier Ltd, 111, pp. 46-50. doi: 10.1016/j.paid.2017.02.003.

Llamas, R. and Uth, T. (2016) 'The luxury of igniting change by giving: Transforming yourself while transforming others lives', Journal of Business Research. Elsevier Inc., 69(1), pp. 166-176. doi: 10.1016/j.jbusres.2015.07.030.

Lynn, M. (2015) 'Explanations of service gratuities and tipping: Evidence from individual differences in tipping motivations and tendencies', Journal of Behavioral and Experimental Economics. Elsevier Ltd., 55, pp. 65-71. doi: 10.1016/j.socec.2015.01.002.

Lynn, M. and Starbuck, M. M. (2015) 'Tipping customs: The effects of national differences in attitudes toward tipping and sensitivities to duty and social pressure', Journal of Behavioral and Experimental Economics. Elsevier Ltd., 57, pp. 158-166. doi: 10.1016/j.socec.2014.07.005.

Matz, S. C., Gladstone, J. J. and Stillwell, D. (2016) 'Money Buys Happiness When Spending Fits Our Personality', Association for Psychological Science, pp. 1-11. doi: 10.1177/0956797616635200.

Miller, J. G., Bland, C., Källberg-shroff, M., Tseng, C., Montes-george, J., Ryan, K., Das, R. and Chakravarthy, S. (2014) 'Culture and the role of exchange vs. communal norms in friendship', Journal of Experimental Social Psychology. Elsevier Inc., 53, pp. 79-93. doi: 10.1016/j.jesp.2014.02.006.

Natter, M. and Kaufmann, K. (2015) 'Voluntary market payments: Underlying motives, success drivers and success potentials', Journal of Behavioral and Experimental Economics. Elsevier Ltd., 57, pp. 149157. doi: 10.1016/j.socec.2015.05.008.

Nielson, M. G., Padilla-walker, L. and Holmes, E. K. (2017) 'How do men and women help? Validation of a multidimensional measure of prosocial behavior', Journal of Adolescence. Elsevier Ltd, 56, pp. 91106. doi: 10.1016/j.adolescence.2017.02.006.

Presiden Republik Indonesia (2004) ‘Undang-Undang Republik Indonesia Nomor 40 Tahun 2004 Tentang Sistem Jaminan Sosial Nasional Dengan', Lembaran Negara Republik Indonesia, 150.

Rotemberg, J. J. (2014) 'Charitable giving when altruism and similarity are linked', Journal of Public Economics. Elsevier B.V., 114, pp. 36-49. doi: 10.1016/j.jpubeco.2012.09.003.

Rudd, M., Aaker, J. and Norton, M. I. (2014) 'Getting the most out of giving: Concretely framing a prosocial goal maximizes happiness', Journal of Experimental Social Psychology. Elsevier Inc., 54, pp. 11-24. doi: 10.1016/j.jesp.2014.04.002.

Sharp, C. and Randhawa, G. (2014) 'Altruism, gift giving and reciprocity in donation: A review of cultural perspective', Transplantation Reviews. Elsevier B.V. doi: 10.1016/j.trre.2014.05.001.

Smith, C. and Davidson, H. (2014) Paradox of Generosity, Oxford University Press.

Sollberger, S., Bernauer, T. and Ehlert, U. (2016) 'Stress influences environmental donation behavior in men', Psychoneuroendocrinology. Elsevier Ltd, 63, pp. 311-319.

Strauss, C., Baer, R. and Cavanagh, K. (2016) 'What is Compassion and How Can We Measure it? A Review of Definitions and Measures', Clinical Psychology Review. The Authors, 47(May), pp. 15-27. doi: 10.1016/j.cpr.2016.05.004.

Su, L. and Hsu, M. K. (2013) 'Service Fairness, Consumption Emotions, Satisfaction, and Behavioral Intentions: The Experience of Chinese Heritage Tourists', Journal of Travel \& Tourism Marketing, 30, pp. 786-805. doi: 10.1080/10548408.2013.835228.

Teh, I. (2015) Universal healthcare coverage in Indonesia, The Economist .

Thabrany, H. (2016) Jaminan Kesehatan nasional, Raja Grafindo Persada .

Urueña, A. and Hidalgo, A. (2016) 'Successful loyalty in e-complaints: FsQCA and structural equation modeling analyses', Journal Business Research. Elsevier Inc., 69, pp. 1384-1389. doi: 10.1016/j.jbusres.2015.10.112. 
Wang, X. and Tong, L. (2015) 'Hide the light or let it shine ? Examining the factors influencing the effect of publicizing donations on donors ' happiness', International Journal of Research in Marketing. Elsevier B.V., pp. 1-7. doi: 10.1016/j.ijresmar.2015.06.001.

Whillans, A. V, Wispinski, N. J. and Dunn, E. W. (2016) 'Seeing wealth as a responsibility improves attitudes towards taxation', Journal of Economic Behavior and Organization. Elsevier B.V., 127, pp. 146154. doi: 10.1016/j.jebo.2016.04.009.

Wilcox, W. B. and Dew, J. (2016) 'The Social and Cultural Predictors of Generosity in Marriage : Gender Egalitarianism, Religiosity, and Familism', Journal of Family Issues, 37(1), pp. 97-118. doi: 10.1177/0192513X13513581.

Yoruk, B. K. (2014) 'Does giving to charity lead to better health? Evidence from tax subsidies for charitable giving Barıs', Journal of Economic Psychology, 45, pp. 71-83. doi: 10.1016/j.joep.2014.08.002.

Zaleskiewicz, T., Gasiorowska, A. and Kesebir, P. (2015) 'The Scrooge effect revisited: Mortality salience increases the satisfaction derived from prosocial behavior', Journal of Experimental Social Psychology. Elsevier Inc., 59, pp. 67-76. doi: 10.1016/j.jesp.2015.03.005.

\begin{tabular}{|c|c|c|c|c|c|c|c|c|}
\hline $\mathrm{N}_{0}$ & Author & Years & Journal & Topic & Design Study & Variable & Outcomes & Description \\
\hline 1 & Aknin et al. & 2013 & $\begin{array}{l}\text { Journal of Economic Behavior and } \\
\text { Organization }\end{array}$ & Consequences & Survey & $\begin{array}{l}\text { Type of donor (Specific } \\
\text { or general) }\end{array}$ & Prosocial act & $\begin{array}{l}\text { Giving money will give more happiness } \\
\text { when participant know how their } \\
\text { money used. }\end{array}$ \\
\hline 2 & Choi $S \&$ Seo & 2017 & $\begin{array}{l}\text { International Journal of Hospitality } \\
\text { Management }\end{array}$ & Attributes & On line survey & $\begin{array}{l}\text { Consumer Personality } \\
\text { (Status seeking or non } \\
\text { status seeking) }\end{array}$ & Consumer Behavior & $\begin{array}{l}\text { Status seeking individual exhibited the } \\
\text { high level of prosocial behavior when } \\
\text { their behavior was recognition } \\
\text { compared to non status seeking }\end{array}$ \\
\hline 3 & $\begin{array}{l}\text { Charles-sire et } \\
\text { al. }\end{array}$ & 2014 & Transfusion and Apheresis Science & $\begin{array}{l}\text { Motivation of being } \\
\text { generous }\end{array}$ & Survey & $\begin{array}{l}\text { Priming } \\
\text { "Loving=Helping" }\end{array}$ & $\begin{array}{l}\text { Intention to give } \\
\text { blood donation }\end{array}$ & $\begin{array}{l}\text { Semantic priming effect to donor } \\
\text { intention and commitment in blood } \\
\text { donation. }\end{array}$ \\
\hline 4 & Chuan \& Samek & 2014 & $\begin{array}{l}\text { Journal of Economic Behavior and } \\
\text { Organization }\end{array}$ & $\begin{array}{l}\text { Motivation of being } \\
\text { generous }\end{array}$ & Experiment & $\begin{array}{l}\text { Declare the donation } \\
\text { with sending postcard } \\
\text { to donor }\end{array}$ & $\begin{array}{l}\text { Amount of future } \\
\text { charity }\end{array}$ & $\begin{array}{l}\text { Declare the donation to recipient can } \\
\text { reduce the intention of donation }\end{array}$ \\
\hline 5 & Crodea & 2014 & $\begin{array}{l}\text { Procedia - Social and Behavioral } \\
\text { Sciences }\end{array}$ & $\begin{array}{l}\text { Definition or } \\
\text { Terminology }\end{array}$ & Literature Review & & & $\begin{array}{l}\text { Gift from an anthropological } \\
\text { perspective differs from the rigid civil } \\
\text { notion of donation. Gift subject to } \\
\text { triple obligation: to give, to receive and } \\
\text { to reciprocate. }\end{array}$ \\
\hline 6 & $\begin{array}{l}\text { Cryder \& } \\
\text { Loewenstein }\end{array}$ & 2015 & $\begin{array}{l}\text { Journal of Experimental Social } \\
\text { Psychology }\end{array}$ & Consequences & Experiment & $\begin{array}{l}\text { Information about the } \\
\text { goal of donor }\end{array}$ & Satisfaction & $\begin{array}{l}\text { Goal gradient helping occurs in part } \\
\text { because late stage effort provide donors } \\
\text { with a heightened sense of prococial } \\
\text { impact, on influential source of } \\
\text { satisfaction of procosial act. } \\
\end{array}$ \\
\hline 7 & Cryder et al. & 2013 & Social Science Research & $\begin{array}{l}\text { Motivation of being } \\
\text { generous }\end{array}$ & Experiment & $\begin{array}{l}\text { Detail information } \\
\text { about the } \\
\text { donor/activity of donor }\end{array}$ & Generosity & $\begin{array}{l}\text { Highlighting detail about charity will } \\
\text { increase generosity. Because they } \\
\text { believe their contribution will give } \\
\text { effect. }\end{array}$ \\
\hline 8 & DeClerk et.al. & 2013 & Brain and Cognition & $\begin{array}{l}\text { Motivation of being } \\
\text { generous }\end{array}$ & Literature Review & & & $\begin{array}{l}\text { People enjoy cooperation behavior } \\
\text { because they enjoy human connection. } \\
\text { Not because of natural compensation. }\end{array}$ \\
\hline & Greenberg & 2014 & $\begin{array}{l}\text { Journal of Economic Behavior and } \\
\text { Organization }\end{array}$ & $\begin{array}{l}\text { Motivation of being } \\
\text { generous }\end{array}$ & Survey & Social Norm & Prosocial Act & $\begin{array}{l}\text { People act prosocial because of or } \\
\text { motivated by intrinsic motivation, but } \\
\text { many motivated by social norm } \\
\text { (extrinsic). }\end{array}$ \\
\hline & Grolleau et al. & 2016 & Research in Economics & $\begin{array}{l}\text { Motivation of being } \\
\text { generous }\end{array}$ & $\begin{array}{l}\text { Experimental } \\
\text { (Public good game) }\end{array}$ & Benefit for others & Generosity & $\begin{array}{l}\text { People are concern about well being of } \\
\text { others. When they receiving other help } \\
\text { or interacting with generous people } \\
\text { (social contagious). }\end{array}$ \\
\hline
\end{tabular}

Table 2. Resume of 30 journals (1) 
Journal of Business and Retail Management Research (JBRMR), Vol. 12 Issue 2

\begin{tabular}{|c|c|c|c|c|c|c|c|c|}
\hline No & Author & Years & Journal & Topic & $\begin{array}{l}\text { Design } \\
\text { Study }\end{array}$ & Variable & Outcomes & Description \\
\hline & Hur & 2013 & $\begin{array}{l}\text { Personality and } \\
\text { Individual Differences }\end{array}$ & $\begin{array}{l}\text { Motivation of being } \\
\text { generous }\end{array}$ & & & & $\begin{array}{l}\text { Social behavior is to achieve positive } \\
\text { outcome for other rather than one self. } \\
\text { The motivation mainly empathy and } \\
\text { moral judgment. }\end{array}$ \\
\hline & Jenssen & 2016 & Current Biology & $\begin{array}{l}\text { Definition or } \\
\text { Terminology }\end{array}$ & Review & & & $\begin{array}{l}\text { Prosocial behavior that intended } \\
\text { benefited other. Various from prosocial } \\
\text { act such as informing, comforting, } \\
\text { sharing and helping. }\end{array}$ \\
\hline & Kandul & 2016 & $\begin{array}{l}\text { Journal of Economic } \\
\text { Psychology }\end{array}$ & $\begin{array}{l}\text { Motivation of being } \\
\text { generous }\end{array}$ & Experiment & $\begin{array}{l}\text { Act of recipient and act } \\
\text { of other donor }\end{array}$ & Giving Money & $\begin{array}{l}\text { Participants are willing to share money } \\
\text { to poorer stranger. Prominent motive } \\
\text { behind are: dislike inequality, warm and } \\
\text { glow and solidarity of needy. }\end{array}$ \\
\hline & Lin & 2015 & $\begin{array}{l}\text { Personality and } \\
\text { Individual Differences }\end{array}$ & Consequences & Survey & $\begin{array}{l}\text { Self Esteem and } \\
\text { Gratitude }\end{array}$ & Well Being & $\begin{array}{l}\text { Gratitude will lead to self esteem which } \\
\text { further lead to well being. }\end{array}$ \\
\hline & Liu and Hao & 2017 & $\begin{array}{l}\text { Personality and } \\
\text { Individual Differences }\end{array}$ & $\begin{array}{l}\text { Motivation of being } \\
\text { generous; Attributes }\end{array}$ & Survey & Social Status & $\begin{array}{l}\text { Reciprocity belief } \\
\text { and Gratitude } \\
\text { sentiment }\end{array}$ & $\begin{array}{l}\text { High statue people give more if } \\
\text { reciprocity. Low status give of out } \\
\text { gratitude. }\end{array}$ \\
\hline 16 & $\begin{array}{l}\text { Llamas and } \\
\text { Thomsen }\end{array}$ & 2016 & $\begin{array}{l}\text { Journal of Business } \\
\text { Research, }\end{array}$ & $\begin{array}{l}\text { Motivation of being } \\
\text { generous }\end{array}$ & $\begin{array}{l}\text { Qualitative } \\
\text { Study }\end{array}$ & & & $\begin{array}{l}\text { Sharing will give the luxury of pleasure, } \\
\text { purpose and connection to human kind. }\end{array}$ \\
\hline & Lynn & 2015 & $\begin{array}{l}\text { Journal of Behavioral } \\
\text { and Experimental } \\
\text { Economics }\end{array}$ & $\begin{array}{l}\text { Motivation of being } \\
\text { generous }\end{array}$ & $\begin{array}{l}\text { On line } \\
\text { survey }\end{array}$ & Motives of tipping & Tipping act & $\begin{array}{l}\text { Desire of giving tip is motivated by help } \\
\text { server, reward good service and fulfill } \\
\text { obligation }\end{array}$ \\
\hline & $\begin{array}{l}\text { Lynn \& } \\
\text { Starbuck }\end{array}$ & 2015 & $\begin{array}{l}\text { Journal of Behavioral } \\
\text { and Experimental } \\
\text { Economics }\end{array}$ & Attributes & Survey & $\begin{array}{l}\text { Attitude to tipping; } \\
\text { sensitivity to social } \\
\text { pressure: sensitivity to } \\
\text { duty }\end{array}$ & Tipp Size & $\begin{array}{l}\text { Tipping prevalence influenced by } \\
\text { national attitude on tipping and } \\
\text { national sensitivity of duty. }\end{array}$ \\
\hline 19 & Miller et al. & 2014 & $\begin{array}{l}\text { Journal of Experimental } \\
\text { Social Psychology }\end{array}$ & Attributes & Experimental & Culture & Reciprocate Behavior & $\begin{array}{l}\text { Indian places greater emphasis than } \\
\text { American do on communal norm in } \\
\text { friend relationship with this effect } \\
\text { unrelated to socioeconomic status. } \\
\text { American more to reciprocal. }\end{array}$ \\
\hline & $\begin{array}{l}\text { Natter and } \\
\text { Kaufmann }\end{array}$ & 2015 & $\begin{array}{l}\text { Journal of Behavioral } \\
\text { and Experimental } \\
\text { Economics }\end{array}$ & $\begin{array}{l}\text { Motivation of being } \\
\text { generous }\end{array}$ & $\begin{array}{l}\text { Literature } \\
\text { Review }\end{array}$ & & & $\begin{array}{l}\text { Reciprocity is the major reason of } \\
\text { people giving voluntary payment. }\end{array}$ \\
\hline
\end{tabular}

Table 3. Resume of 30 journals (2) 
Journal of Business and Retail Management Research (JBRMR), Vol. 12 Issue 2

\begin{tabular}{|c|c|c|c|c|c|c|c|c|}
\hline No & Author & Years & Journal & Topic & $\begin{array}{l}\text { Design } \\
\text { Study }\end{array}$ & Variable & Outcomes & Description \\
\hline 21 & Nielson et al. & 2017 & Journal of Adolescence & Attributes & Survey & Gender & Procosial Act & $\begin{array}{l}\text { There is no difference of man and } \\
\text { woman in their prosocial act. }\end{array}$ \\
\hline 22 & Rotemberg & 2014 & $\begin{array}{l}\text { Journal of Public } \\
\text { Economics }\end{array}$ & $\begin{array}{l}\text { Motivation of being } \\
\text { generous }\end{array}$ & $\begin{array}{l}\text { Conceptual } \\
\text { Paper }\end{array}$ & & & People donate when other donate \\
\hline 23 & Rudd et al. & 2014 & $\begin{array}{l}\text { Journal of Experimental } \\
\text { Social Psychology }\end{array}$ & Consequences & Experiment & Framing Goal & Happiness & $\begin{array}{l}\text { Framing concrete goal will make } \\
\text { prosocial bring greater happiness. }\end{array}$ \\
\hline 24 & $\begin{array}{l}\text { Sharp and } \\
\text { Randhawa }\end{array}$ & 2014 & $\begin{array}{l}\text { Transplantation } \\
\text { Reviews }\end{array}$ & $\begin{array}{l}\text { Motivation of being } \\
\text { generous }\end{array}$ & $\begin{array}{l}\text { Literature } \\
\text { Review }\end{array}$ & & & $\begin{array}{l}\text { People help because they concern } \\
\text { about welfare of others and driven by } \\
\text { empathy. }\end{array}$ \\
\hline 25 & Sollberger et al. & 2016 & $\begin{array}{l}\text { Psychoneuroendocrinol } \\
\text { ogy }\end{array}$ & $\begin{array}{l}\text { Motivation of being } \\
\text { generous }\end{array}$ & $\begin{array}{l}\text { Experiment } \\
\text { al }\end{array}$ & Donation behavior & Happiness & $\begin{array}{l}\text { Stress may increase prosocial behavior } \\
\text { through the mechanism of emotion } \\
\text { regulation. However, stress induced } \\
\text { also decreases the amount of donation. }\end{array}$ \\
\hline 26 & Strauss et.al. & 2016 & $\begin{array}{l}\text { Clinical Psychology } \\
\text { Review }\end{array}$ & $\begin{array}{l}\text { Definition or } \\
\text { Terminology }\end{array}$ & $\begin{array}{l}\text { Literature } \\
\text { Review }\end{array}$ & & & $\begin{array}{l}5 \text { Component of compassions: } 1 \text {. } \\
\text { Recognition of suffering; } 1 \text {. Understand } \\
\text { it universally; 3. Felling sympathy, } \\
\text { empathy and concern; } 4 \text {. Tolerance the } \\
\text { distress; } 5 \text {. Motivation to act. }\end{array}$ \\
\hline 27 & Wang \& Tong & 2015 & $\begin{array}{l}\text { Journal of Research in } \\
\text { Marketing }\end{array}$ & Consequences & Experiment & $\begin{array}{l}\text { Publication after } \\
\text { charity act }\end{array}$ & $\begin{array}{l}\text { Happiness and Future } \\
\text { Charity giving }\end{array}$ & $\begin{array}{l}\text { Publishing prosocial act may donor post- } \\
\text { donation happiness and may influence } \\
\text { future prosocial intention. }\end{array}$ \\
\hline 28 & Whillans et al. & 2016 & $\begin{array}{l}\text { Journal of Economic } \\
\text { Behavior and } \\
\text { Organization }\end{array}$ & Consequences & Survey & $\begin{array}{l}\text { Wealth } \\
\text { Responsibility }\end{array}$ & Taxation Perception & $\begin{array}{l}\text { Novel lever will encourage and make } \\
\text { people feel better in paying tax. }\end{array}$ \\
\hline & Yoruk & 2014 & $\begin{array}{l}\text { Journal of Economic } \\
\text { Psychology }\end{array}$ & Consequences & Survey & Generosity & Health Outcomes & $\begin{array}{l}\text { Charitable giving has a positive spill } \\
\text { over affect on overall health status and } \\
\text { decrease the probability of suffering } \\
\text { from several important health problem. }\end{array}$ \\
\hline & $\begin{array}{l}\text { Zaleskiewicz et } \\
\text { al. }\end{array}$ & 2015 & $\begin{array}{l}\text { Journal of Experimental } \\
\text { Social Psychology }\end{array}$ & $\begin{array}{l}\text { Motivation of being } \\
\text { generous }\end{array}$ & Survey & $\begin{array}{l}\text { Amount of money } \\
\text { given; Mortality } \\
\text { salient }\end{array}$ & Satisfaction & $\begin{array}{l}\text { People choose to behave more } \\
\text { generously after mortality thought. This } \\
\text { has more to do with one's personal } \\
\text { satisfaction of others. }\end{array}$ \\
\hline
\end{tabular}

Table 4. Resume of 30 journals (3) 